\title{
Our Results in Penile Fractures
}

\section{Penil Fraktür Sonuçlarımız}

\section{Tufan Süelözgen1, Hakan Türk2, Sıtkı Ün3, Osman Köse3, Yusuf Özlem Illbey1, Ferruh Zorlu1}

\author{
1Tepecik Training and Research Hospital, Clinic of Urology, Izmir, Turkey \\ 2Dumlupınar University Evliya Çelebi Training and Research Hospital, Clinic of Urology, Kütahya, Turkey \\ ${ }^{3}$ Katip Çelebi University Atatürk Training and Research Hospital, Clinic of Urology, Izmir, Turkey
}

\section{What's known on the subject? and What does the study add?}

Literature review and referral of penile fracture patients to surgery without losing time.

\begin{abstract}
\section{Introduction}

Penile fracture is a urological emergency caused by direct trauma to an erected penis, tearing the tunica albuginea in the corpus cavernosum. The preferred treatment method is draining the hematoma and surgical repair of tunica albuginea tear as soon as possible following diagnosis.

\section{Materials and Methods}

Forty-nine patients who were diagnosed with penile fracture between January 2009 and December 2014 were reviewed. Physical examination was performed to see the extent of penile hematoma, the side of the penile curvature and the presence of blood in the external meatus. Two patients who were diagnosed with urethrorrhagia underwent retrograde urethrogram for urethral injury. In all patients, penile skin was peeled using a circular subcoronal degloving incision and tunica tear was repaired using absorbable suture materials. The patients were then followed for painful erections, penile deformities and erection angles.
\end{abstract}

\section{Results}

The average age of the 49 patients, who were included in the study, was 36.5 years (21-65). In their etiological questioning, most patients reported the fracture occurring during sexual intercourse. Retrograde urethrography was indicated in 2 patients with blood in the external meatus and were diagnosed with urethral injury. The patients were taken to emergency surgery. Tunica defects varied between 1 and $2 \mathrm{~cm}$. Incomplete urethral injuries were primarily repaired around 18 French Foley catheter. None of the patients reported penile deformity or painful erections. Their erection angles were found to be within the normal range.

\section{Conclusion}

Even though it is a relatively rare condition, penile fractures are so important that might cause serious complications when not treated surgically. A thorough anamnesis and physical examination suffice for diagnosis.

\section{Keywords}

Penile fracture, penis, sexual intercourse, erection

\section{ÖZ}

\section{Amaç}

Penil fraktür, ereksiyon halindeki penisin direkt travmaya maruz kalması sonucu gelişen korpus kavernozumda tunika albugineanın yırtılması ile ortaya çıkan ürolojik acil bir durumdur. Önerilen tedavi tanı konulduktan sonraki en kısa zamanda hematomun boşaltılması ve tunika albugineadaki yırtığın tamir edilmesidir.

\section{Gereç ve Yöntem}

Ocak 2009 ile Aralık 2014 tarihleri arasında penil fraktür tanısı konularak tedavisi yapılan 49 hasta değerlendirildi. Yapılan fizik muayene ile penil hematomun yayılımı, penil eğriliğin hangi tarafta olduğu ve eksternal meatusta kan olup olmadığına bakıldı. Üretroraji saptanan iki hastada üretra yaralanması düşünülerek retrograd üretrografi çekildi. Hastaların hepsinde sirküler subkoronal sirkümsizyon insizyonla girilerek penis derisi soyuldu ve tunikadaki yırtık emilebilir sütür materyali ile onarıldı. Takip edilen hastalar ağrılı ereksiyon, penil deformite ve ereksiyon derecesi açısından değerlendirildi.

Bulgular

Çalışmaya dahil edilen 49 hastanın ortalama yaşı 36,5 (21-65) yıl idi. Operasyon öncesinde etiyolojik sorgularında hastalar çoğunlukla fraktürün cinsel ilişki esnasında olduğunu ifade etti. İki hastanın eksternal meatusunda kan görülmesi üzerine retrograd üretrografi çekildi ve üretra yaralanması tespit edildi. Hastalar acilen operasyona alındı. Tunikadaki defektler 1-2 cm arasında değişmekteydi. İki hastada mevcut olan inkomplet üretra yaralanmaları 18 French Foley sonda etrafında primer olarak onarıldı. Hastaların hiçbirinde penil deformite ve ağrılı ereksiyon saptanmadı. Ereksiyon açıları normal olarak bulundu.

\section{Sonuç}

Penil fraktür çok sık karşılaşılan bir durum olmasa da cerrahi tedavi ile tedavi edilmediğinde ciddi komplikasyonlara yol açan bir durumdur. Tanı için anamnez ve fizik muayene yeterlidir.

Anahtar Kelimeler

Penil fraktür, penis, cinsel ilişki, ereksiyon

\section{Correspondence}

Hakan Türk MD, Dumlupınar University Evliya Çelebi Training and Research Hospital, Clinic of Urology, Kütahya, Turkey

Phone: +90 5555516885 E-mail: hkntrk000@hotmail.com Received: 12.04.2016 Accepted: 13.04.2016

This study was 24th Turkish Urology Congress. 


\section{Introduction}

Penile fracture is a urological emergency that is caused by direct trauma to an erected penis, tearing the tunica albuginea in the corpus cavernosum. The tear in tunica is mostly unilateral, although may be occasionally bilateral (1). There may also a concomitant urethral injury depending on the degree of trauma (2). Clinically, the patients hear a snapping sound during erection followed by severe pain, rapid loss of erection, swelling, ecchymosis and penile deviation (3). The preferred treatment method is draining of the hematoma and surgical repair of the tunica albuginea tear as soon as possible following diagnosis (4).

\section{Materials and Methods}

Forty-nine patients, who were diagnosed and treated with penile fractures between January 2009 and December 2014, were reviewed. Three patients were excluded for not attending control exams. A total of 46 patients were eventually included in the study. First, a careful history taking was completed at the time of admittance. The patients were inquired about the causes of the fracture. Physical examination was performed to see the extent of penile hematoma, the side of the penile curvature and blood presence in the external meatus. Two patients, who were diagnosed with urethrorrhagia, underwent retrograde urethrogram for urethral injury. Urethral injury was detected as a result of opaque matter extravasation. In all patients, the penile skin was peeled by circular subcoronal degloving incision and tunica tear was repaired using 2/0 VICRYL ${ }^{\circledR}$ (polyglactin 910) absorbable suture materials. Right corpus cavernosum rupture was present in 25 patients (54\%), left corpus cavernosum rupture in 19 (41\%) and bilateral corpus cavernosum rupture was present in 2 patients (5\%). In two of the patients with urethral injury, primary repair was performed on the defect around 18 Fr (French) Foley catheter. All patients underwent elastic bandage for 24 hours. Broad spectrum antibiotics and anti-inflammatory medication were started. Medical therapy was scheduled for 5 days. Patients who underwent urethral repair were discharged after removing the Foley catheters on day 7 and the rest of the patients were discharged within 24 hours. The patients were followed up for 17 (3-30) months in average for painful erection and presence and degree of penile deformities. Additional uroflowmetry and urethrography were performed in patients having undergone urethral repair.

\section{Results}

The average age of the 49 patients, who were included in the study was 36.5 years (21-65). In their etiological questioning before surgery, most patients reported the fracture occurring during sexual intercourse. Yet, some causes were also reported as etiological causes although we are in the opinion that these may not be true etiological causes due to various reasons (Table 1). Patients having been diagnosed with physical examination presented with penile hematoma, ecchymosis and swelling. Retrograde urethrography was indicated in 2 patients with blood in the external meatus and were diagnosed with urethral injury. The patients were taken to emergency surgery. The extent of the tunica defect varied between 1 and $2 \mathrm{~cm}$. Incomplete urethral injuries were primarily repaired around $18 \mathrm{Fr}$ Foley catheter. One patient with urethral injury had rupture in both corpora cavernosa, whereas the other had only unilateral rupture. The locations of the corpus cavernosa ruptures are provided in Table 1. All patients underwent drainage with Foley catheter. No complication developed pre- or post-operatively. First controls were started in month 3. They were physically examined and questioned for erection. None of the patients reported penile deformity or painful erections. Their erection angles were found to be within the normal range. The patients having undergone primary repair for urethral injury were checked with uroflowmetry. One patient who reported micturition complaints was suspected for stenosis. Stenosis was confirmed by retrograde urethrography and treated with dilatation. Restenosis was not detected in this patient.

\section{Discussion}

Penile fractures are rare injuries although the real incidence remains unknown (5). Etiologically, the most common cause of penile fracture is sexual intercourse (33-60\%) (6). The rate of fracture formation during intercourse was found to be $42 \%$ in our study. Many other causes, including turning during sleep, falling from bed, abnormal bending during masturbation or attempting to put on trousers with an erected penis, have been reported (7). During erection, the tunica albuginea thins from $2 \mathrm{~mm}$ to $0.25-0.5 \mathrm{~mm}$ being a predisposing factor for penile fracture (8). Patients present with typical history and physical examination findings. Severe pain, sudden onset erectile dysfunction, swelling and ecchymosis are reported following fracture. Although some authors suggest preoperative diagnostic cavernosography for all patients (9), majority are in the opinion that typical history and physical examination findings would suffice for diagnosis excluding the need for extra tests since cavernosography may give misleading results $(10,11)$. Penile ultrasonography and magnetic resonance imaging modalities have limited success $(12,13)$. Urethrography should be added in the spectrum of tests in the presence of urethrorrhagia or hematuria which may be suggesting urethral injury (14). All patients in our study were diagnosed with history taking and physical examination. We performed retrograde urethrography in two patients due to presence of blood in the meatus and detected urethral injury. In a study done in forty patients (15), concomitant urethral injury rate was reported to be 7.5\%, which was 4.5\% in our study. Until 1970's, penile fractures were mostly treated with conservative management including penoscrotal elevation, compression, or antibiotics and anti-inflammatory medication (16). Emergency surgery was first performed by Meares in 1971 for drainage of hematoma and primary repair of the tear in the corpus cavernosum. Penile fractures present with major complications, such as penile deformity, painful erection, challenged coitus, poor erection quality, and pseudodiverticula. Such complications have been reported in the range of 10-30\% particularly in the conservatively treated patients whereas the same remains

\begin{tabular}{|l|l|l|}
\hline \multicolumn{2}{|c|}{ Table 1. Patient distribution according to fracture causes } \\
& Number of patients & Ratio \\
\hline Sexual intercourse & 19 & $42 \%$ \\
\hline Masturbation & 9 & $19 \%$ \\
\hline Turning in sleep & 7 & $15 \%$ \\
\hline Falling from bed & 5 & $11 \%$ \\
\hline Other & 6 & $13 \%$ \\
\hline Total & 46 & $100 \%$ \\
\hline
\end{tabular}


between 0 and $10 \%$ in the surgically treated cases $(17,18,19,20)$. No complication has been reported in our patient group. Another major advantage of surgical repair of penile fractures is shorter hospital stay, which varies between 4 and 71 days in conservatively treated patients but considerably shorter in the surgically treated patients $(21,22)$. Hospital stay did not exceed 24 hours in our study.

\section{Conclusion}

Even though it is a relatively rare condition, penile fractures might cause serious complications when not treated surgically. A thorough anamnesis and physical examination suffice for diagnosis. The possibility of urethral injury should always be considered. Emergency surgical repair may provide successful outcomes.

\section{Ethics}

Ethics Committee Approval: Ethics committee approval was not obtained becasue of retrospective study, Informed consent: Written informed consent was not obtained from patient/patients becasue of retrospective study.

Peer-review: Externally peer-reviewed.

\section{Authorship Contributions}

Concept:Tufan Süelözgen, Design: Hakan Türk, Data Collection or Processing: Hakan Türk, Sıtkı Ün, Analysis or Interpretation: Tufan Süelözgen, Osman Köse, Yusuf Özlem İlbey, Ferruh Zorlu, Literature Research: Tufan Süelözgen, Hakan Türk, Writing: Tufan Süelözgen.

Conflict of Interest: No conflict of interest was declared by the authors.

Financial Disclosure: The authors declared that this study has received no financial support.

\section{References}

1. Asgari MA, Hosseini SY, Safarinejad MR, Samadzadeh B. Penile fractures: eveluation, therapeutic approaches and long-term results. J Urol 1996;155:148-149.

2. Tsang $T$, Demby AM. Penile fracture with urethral injury. J Urol 1992;147:446-448.

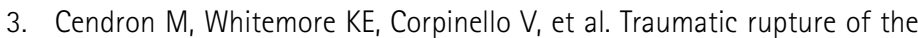
corpus cavernosum: evaluation and managament. J Urol 1990;144:987991.
4. Özkan S, Yiğitbaşı O, Özmen E, Ersoy H, Topaloğlu H, Yalçınkaya F. Penis fraktürü tedavi ve takibi. Bulletin of Urooncology 1991;2:132-133.

5. Oesterwitz $H$, Bick $C$, Braun E. Report of 6 cases and review of the literature. Int Urol Nephrol 1984;16:123-127.

6. Nicolaisen GS, Melamud A, Williams RD, McAninch JW. Rupture of the corpus cavernosum: surgical treatment. J Urol 1983;130:917-919.

7. Meares EM. Traumatic rupture of the corpus cavernosum. J Urol 1971;105:407-408.

8. Karadeniz T, Topsakal M, Ariman A, Erton $H$, Basak D. Penile fracture: differantial diagnosis, management and outcome. Br J Urol 1996;77:279281.

9. Dever DP, Saraf PG, Catanese RP, Feinstein MJ, Davis RS. Penile fracture: operative management and cavernosography. Urology 1983;22:394-396.

10. Nicely ER, Costabile RA, Moul JW. Rupture of the deep dorsal vein of the penis during sexual intercourse. J Urol 1992;147:150-152.

11. Grosman H, Gray RR, St Louis EL, Casey R, Keresteci AG, Elliott DS. The role of corpus cavernosography in acute fracture of the penis. Radiology 1982;144:787-788.

12. Wallton JK. Fracture of the penis with laceration of the urethra. $\mathrm{Br} J$ Urol 1979;51:308-309.

13. Uder $M$, Gohl $D$, Takahashi $M$, et al. MRI of penile fracture: diagnosis and therapeutic follow-up. Eur Radiol 2002;12:113-120.

14. Parrillo SJ, Suzanna EK, Finkelstein L. Fracture of the penis. Ann Emerg Med 1980;10:376-378.

15. Beysel M, Tekin A, Gurdal M, Yücebaş E, Sengör F. Evaluation and treatment of penile fractures: accuracy of clinical diagnosis and the value of corpus cavernosograpy. Urology 2002;60:492-496.

16. Farah R, Stiles R Jr, Cerny JC. Surgical treatment of deformity and coital difficulty in healed traumatic rupture of corpora cavernosa. J Urol 1978;120:118-120.

17. Kalash SS, Young JD Jr. Fracture of penis: Controversy of surgical versus conservative tretament. Urology 1984;24:21-24.

18. Uygur MC, Gülerkaya B, Altuğ U, Germiyanoğlu C, Erol D. 13 years'experience of penile fracture. Scand J Urol Nephrol 1997;31:265-266.

19. Zargooshi J. Penile fracture in Kermanshah, Iran: report of 172 cases. J Urol 2000;164:364-366.

20. Lee SH, Bak CW, Choi MH, Lee HS, Lee MS, Yoon SJ. Trauma to male genital organs: a 10-year review of 156 patients, including 118 treated by surgery. BJU Int 2008;101:211-215.

21. Kılıçarslan H, Gökçe G, Kaya K, Ayan S, Gültekin Y. Penis fraktürlerinin cerrahi tedavisi. Ulus Travma Acil Cerrahi Derg 2003;9:54-59.

22. Soylu A, Günes $A$, Uğraş My, İpek $D$, Baydinç C. Penil Fraktür: 11 yıllık deneyim. Türk Üroloji Dergisi 2003;29:344-350. 